\title{
Readiness Level Students in Electrical Engineering from the Aspect Technical Skills on the Formation Workability at Polytechnic
}

\author{
Mohd Nur Hafiz Fauzi, Azman Hasan, Noorazman Abd Samad, Mohd Jalil Ahmad, Suhaili Hanafi \\ Faculty of Technical and Vocational Education, University Tun Hussein Onn Malaysia, Johor, Malaysia \\ Email address: \\ pnurhafiz@gmail.com (M. N. H. Fauzi), azmanh@uthm.edu.my (A. Hasan), noorazman@uthm.edu.my (N. A. Samad), \\ mohdjali11805@gmail.com (M. J. Ahmad), suhailihanafi@gmail.com (S. Hanafi)

\section{To cite this article:} \\ Mohd Nur Hafiz Fauzi, Azman Hasan, Noorazman Abd Samad, Mohd Jalil Ahmad, Suhaili Hanafi. Readiness Level Students in Electrical \\ Engineering from the Aspect Technical Skills on the Formation Workability at Polytechnic. International Journal of Vocational Education \\ and Training Research. Vol. 2, No. 5, 2016, pp. 28-33. doi: 10.11648/j.ijvetr.20160205.11
}

Received: July 27, 2016; Accepted: August 25, 2016; Published: December 29, 2016

\begin{abstract}
Unemployed graduates continue to be a growing problem in Malaysia. There are employers who consider academic competence alone is not enough and started asking for higher education institutions to produce graduates who are equipped with technical skills. This study is a survey to determine the readiness of electrical engineering students from the technical skills of forming workability in polytechnics. A total of 113 respondents were selected for the study. The instrument used in this study is a questionnaire containing 60 items. A pilot study was conducted to determine the value of alpha for the instrument in which the alpha value for the aspect of technical skills is $\alpha=0.962$ and for the workability is $\alpha=0954$. Data were analyzed using the Statistical Package for Social Science Version 20 (SPSS 20). The descriptive analysis in the form of mean score was used to see the readiness of students. The study found that the level of preparedness of students in electrical engineering from the technical skills of forming workability in polytechnics are at high level. The study also showed that there is a difference between male and female students of technical aspects that affect the willingness of students to the formation of workability.
\end{abstract}

Keywords: Technical Skills, Electrical Engineering, Workability

\section{Introduction}

Skilled labor and productive is a prerequisite to ensure the industrial sector in Malaysia continues to grow and thrive. Therefore, high-quality workforce with diverse skills, particularly in terms of technical skills needed by employers and industry to ensure a favorable investment climate and the competitiveness of Malaysian products in the world market (Abu Bakar and Aziz, 2011). According to a study by the National Economic Action Council in discussions Study on the Unemployment Situation in Malaysia2003 which found that some causes of unemployment among graduates, including a lack of training in preparation for entering the profession, the lack of quality and usability of its graduates and the lack of skills of graduates in aspects such as a second language management and communication skills. The marketability concept must be considered in this situation because it can reflect a person is able to work with the knowledge, skills and characteristics that make a person a useful and valuable in certain contexts (Elinor Edvardsson Jungert Stiwne and Thomas, 2007).

\section{Related Work}

Readiness skills of students in meeting the demanding needs of the industry may be influenced by several factors. Among them is through the curriculum, facility (infrastructure), teaching, and learning during their study. Based curriculum, through existing courses offered in polytechnics, many emphasize technical skills in a "handson" but the facilities available at the polytechnic is limited.

This problem has affected the teaching and learning process. According to Adnan (2008), if the concerns and attitudes of the equipment in the workshop such as machine 
tools and not be aware, the process of teaching and learning in the workshop can not be executed properly. This affects the formation of individuals who have high skills as desired by the country. Facilities equipment in the workshop or laboratory should be taken seriously to provide sufficient practical training to the students. This is to prepare the individual in the field of blue-collar jobs. This was stated by Mahathir (2003), in fulfillment of the country's labor needs, the government should improve the educational needs of technical skills in schools and institutions of higher learning through practical training in engineering workshops and vocational training in the industry.

To meet the demand for skills-based education, especially in engineering who have hands-on training, capacity building training centers in Malaysia are very much needed skills. Most employers have expressed dissatisfaction with the lack of higher learning of the existence of a "skills gap" which is required by the employer to the skills possessed by graduates (Dickinson, 2000). According to Hesketh (1999), there is evidence that clearly shows the occurrence of "mismatch" of skills required by employers and their ability to take on graduates who have the skills. The industry also believes that, it is more effective if these graduates get good skills from courses in school compared develop their own skills. Therefore, it is important to develop the higher education curriculum that can meet the needs of the market and industry.

Students are individuals who play a key role in producing graduates who have high technical skills uplift the name of the university in the field of education. Most students do not associate the work with curriculum requirements contained in school. They only learn what teachers say and only enshrined in the syllabus. Only a handful of students who think and explore existing knowledge to make themselves conversant with learning something either theoretically or practically. Thus, there are three factors to the attention of researchers associated with the relationship between students and skills. These factors are the methods, procedures and techniques to aspects of technical skill itself. As a result of these things, the study should be conducted to determine the level of readiness of students of the polytechnic technical skills include methods, procedures and techniques for forming workability and the existence of different levels of readiness among male and female before stepping into the world of work.

\section{Methodology}

This study is a quantitative survey using a questionnaire as an instrument for information. According Piaw (2006), design review is a manual procedure to get the data. Selection of study design involves a strategic plan that must be made is to allow the chosen approach provides insights valid and reliable in achieving the objectives and answer the research questions. According Konting (2009), the survey is used to describe a phenomenon that is taking place or the relationship between the variables that exist in the study. Method of distributing the questionnaire is one way to gather information concerning the respondents to the public. All data collected and obtained from respondents will be presented in the form of descriptive statistics such as mean, standard deviation and percent. In this study, a questionnaire was distributed to respondents that polytechnic students selected to determine the readiness of electrical engineering students from the technical skills of forming workability.

\subsection{The Instrument}

The instrument is a measuring device to obtain data from the sample. According Piaw (2006), the questionnaire should be in accordance with the willingness of respondents. The questionnaire also more easily administered, which refers to the process of distribution of questions and also the process of analyzing the data collected back after question (Abdul Ghafar, 2006). According Konting (2009), the use of questionnaires is an easy way to get cooperation from respondents. In this study, the instruments used are questionnaires, seen as appropriate for the form of surveys and studies will help achieve the objectives more effectively. Through the use of questionnaires may also improve the accuracy and validity of the study and the advantages of using the questionnaire are required no time to answer the questionnaire but it is more cost-effective. According to Idris (2013), a questionnaire was used to measure opinions, attitudes or knowledge and the type of questions also can be nominal, ordinal or scale. In general, the survey questionnaire was divided into three parts, namely Part A, Part B and Part C. The researchers divided the set questionnaire into three parts responding to the objectives of the study as described in Table 1

Table 1. Item Questionnaire Of Study.

\begin{tabular}{lll}
\hline Part & question & Item involved \\
\hline $\begin{array}{l}\text { Part A } \\
(3 \text { item })\end{array}$ & Background respondents & Gender, location and polytechnic courses \\
$\begin{array}{l}\text { Part B } \\
(30 \text { item })\end{array}$ & Items related aspects of technical skills & This section examines the aspects of technical skills covers the methods, \\
Part C & & procedures and techniques. \\
$(30$ item $)$ & Items related aspects of the Division workability & $\begin{array}{l}\text { Workability aspects include communication skills, problem solving and } \\
\text { critical thinking. }\end{array}$ \\
\hline
\end{tabular}

Part A is the demographic data of respondents who use multiple-choice questions in the background collecting data respondents. Part B, and $\mathrm{C}$ are formed using a Likert scale, involving variables of the technical skills and workability. Setiap respondents should indicate their response options appropriate to scale Likert. 
Table 2. Analysis Results For Sample Cronbach Alpha Pilot Study.

\begin{tabular}{lll}
\hline Variable & Alpha value & Number of Item \\
\hline Technical Skill & 0.962 & 30 \\
Workability & 0.954 & 30 \\
\hline
\end{tabular}

\subsection{Result and Analysis}

Analysis of data is one thing that contributes to the success of the study. Data and information obtained through the analysis will be descriptive and inferential statistics using computer software "SPSS 20.0 for windows" (Statistical Packages For Social Sciences). Descriptive statistical procedures needed to establish a profile of the sample in which the frequency distribution exhibited by each score. In this study, the analysis is done in the form of mean, frequency and percentage. Its data is divided into three levels, namely low, medium and high.

Table 3. Interpretation of Mean Score.

\begin{tabular}{ll}
\hline Range Score Min & Phase \\
\hline $1.00-2.33$ & low \\
$2.34-3.67$ & medium \\
$3.68-5.00$ & high \\
\hline
\end{tabular}

Source: Landell (1997)

Table 4. Summary Of Test Aspect.

\begin{tabular}{|c|c|c|}
\hline Num & Research Question & Statistical Analysis \\
\hline 1. & $\begin{array}{l}\text { What is the level of readiness of the } \\
\text { method of forming workability? }\end{array}$ & $\begin{array}{l}\text { descriptive statistics } \\
\text { (score min) }\end{array}$ \\
\hline 2. & $\begin{array}{l}\text { What is the level of readiness of students } \\
\text { of the procedural aspects of the formation } \\
\text { workability? }\end{array}$ & $\begin{array}{l}\text { descriptive statistics } \\
\text { (score min) }\end{array}$ \\
\hline 3. & $\begin{array}{l}\text { What is the level of readiness of students } \\
\text { of technical aspects of the formation } \\
\text { workability? }\end{array}$ & $\begin{array}{l}\text { descriptive statistics } \\
\text { (score } \min \text { ) }\end{array}$ \\
\hline 4. & $\begin{array}{l}\text { What is the level of preparedness of } \\
\text { students in terms of workability? }\end{array}$ & $\begin{array}{l}\text { descriptive statistics } \\
\text { (score } \min \text { ) }\end{array}$ \\
\hline 5. & $\begin{array}{l}\text { What is there a difference between the } \\
\text { sexes in terms of technical skills that } \\
\text { affect the willingness of students to } \\
\text { formation workability? }\end{array}$ & $\begin{array}{l}\text { statistical Inference } \\
\text { (Mann Whitney Test) }\end{array}$ \\
\hline
\end{tabular}

In this study, the researcher used descriptive statistics to answer the research questions. The researchers used an average mean score and standard deviation to determine the level of readiness of technical skills and workability based on the research questions. Mann Whitney $U$ test was used for the purpose of identifying whether there is a difference between the sexes in terms of technical skills that affect the willingness of students to the formation of workability.

The analysis conducted in Part A of the questionnaire, this study will give an overall picture related to the background of the respondents involved in this research. Through the data, there are three main items contained in Part A in which the items are listed as follows:

(i) Gender

(ii) Course of Study

(iii) The location Polytechnic
Table 5. Distribution of frequency and percentage of respondents by gender.

\begin{tabular}{lll}
\hline Gender & Frequency & Percent (\%) \\
\hline Male & 61 & 54 \\
Female & 52 & 46 \\
Total & 113 & 100 \\
\hline
\end{tabular}

Table 6. Distribution of frequency and percentage of respondents by course of study

\begin{tabular}{lll}
\hline Course of study & Frequency & Percent (\%) \\
\hline Electrical Engineering & 59 & 52.2 \\
Electronic Engineering & 54 & 47.8 \\
Total & 113 & 100 \\
\hline
\end{tabular}

Table 7. Distribution of frequency and percentage of respondents according to the location of the polytechnic.

\begin{tabular}{lll}
\hline Location & Frequency & Percent (\%) \\
\hline Politeknik Merlimau & 36 & 31.9 \\
Politeknik Tunku Sultanah Bahiyah & 37 & 32.7 \\
Politeknik Sultan Abdul Halim & 40 & 35.4 \\
Total & 113 & 100 \\
\hline
\end{tabular}

Next, the researchers discuss the findings obtained in answering the research questions that first second, third and fourth in which researchers use descriptive statistics which involves the use of mean scores.

Table 8. Distribution of mean scores for the aspects of the method.

\begin{tabular}{l|ll}
\hline Statement Item & Min & Interpretation \\
\hline $\begin{array}{l}\text { I identify work objectives before making a } \\
\text { workshop. }\end{array}$ & 3.74 & High \\
$\begin{array}{l}\text { I apply existing knowledge in the work of } \\
\text { wiring. }\end{array}$ & 4.13 & High \\
$\begin{array}{l}\text { I know the hardware required for the } \\
\text { workshop. }\end{array}$ & 4.74 & High \\
$\begin{array}{l}\text { I plan to work before the workshop. } \\
\begin{array}{l}\text { I know the expectations of the workshop. } \\
\text { I make findings of workshop discussions with } \\
\text { members of the group. }\end{array}\end{array}$ & 2.74 & Medium \\
$\begin{array}{l}\text { I asked the lecturer if there are any problems } \\
\text { during the workshop. }\end{array}$ & 4.74 & Medium \\
$\begin{array}{l}\text { I give the good cooperation between members } \\
\text { of the group to achieve the objectives of the } \\
\text { workshop. }\end{array}$ & 3.74 & High \\
$\begin{array}{l}\text { I can analyze the results of the workshop work } \\
\text { well. }\end{array}$ & 3.74 & High \\
$\begin{array}{l}\text { I can explain the results of the workshop are } \\
\text { available both verbally. }\end{array}$ & 3.74 & High \\
\begin{tabular}{l} 
Total Score Mean \\
\hline
\end{tabular} & 3.69 & High \\
\hline
\end{tabular}

Referring table 8 to the results of this study showed that the average distribution of the mean score on the aspect of the method is high. Total score mean 3.69 shows that the aspects of the technical skills is high and the respondents able to design and analyze before carrying out any work or workshops. 
Table 9. Distribution of mean scores for the procedural aspects.

\begin{tabular}{lll}
\hline Statement Item & Min & Interpretation \\
\hline I understand the rules of the workshop. & 4.13 & High \\
I know the safety measures in handling objects / & 3.49 & Medium \\
materials weight. & & \\
I apply the security features when operating & 3.49 & Medium \\
electrical appliances. & 3.42 & Medium \\
I understand the industry safety standards. & 3.74 & High \\
I use safety equipment properly. & 4.13 & High \\
I understand the safety symbols. & 4.00 & High \\
I can identify dangerous areas. & 4.35 & High \\
I put the equipment in the place after use. & 3.00 & Medium \\
I always use a safety boot in the work area. & 3.35 & Medium \\
I'm not joking when at the workshop. & 3.71 & High \\
Total Score Mean & & \\
\hline
\end{tabular}

Referring table 9 to the results of this study showed that the average distribution of the mean score on the aspect of the procedure is high. The overall mean value indicates a high level of 3.71. This many respondents also showed a high level of aspects procedures, technical skills. The mean score for this item procedural aspects are balanced between mean high and mean simple.

Table 10. Distribution of mean scores for the aspects of technic.

\begin{tabular}{|c|c|c|}
\hline Statement Item & Min & Interpretation \\
\hline I could use a good soldering tools. & 3.39 & Medium \\
\hline I can choose soldering tool correctly. & 3.74 & High \\
\hline I can choose the right tool with EDM soldering. & 4.35 & High \\
\hline $\begin{array}{l}\text { I am adept at using various types of analog } \\
\text { meters. }\end{array}$ & 3.35 & Medium \\
\hline $\begin{array}{l}\text { I can test continuity (continuity) circuit wiring } \\
\text { by using a multi-meter. }\end{array}$ & 3.19 & Medium \\
\hline I am proficient in reading resistor code. & 3.76 & High \\
\hline $\begin{array}{l}\text { I was able to explain the function of a transistor } \\
\text { properly. }\end{array}$ & 3.76 & High \\
\hline $\begin{array}{l}\text { I can change a faulty light switch in the wiring } \\
\text { system of the phases using the right tools. }\end{array}$ & 2.38 & Medium \\
\hline $\begin{array}{l}\text { I skilled install fluorescent lamps with the right } \\
\text { tools. }\end{array}$ & 3.68 & High \\
\hline $\begin{array}{l}\text { I efficiently use the tools to finish the job } \\
\text { (screwdriver, meter testers and so on). }\end{array}$ & 4.50 & High \\
\hline Total Score Mean & 3.61 & Medium \\
\hline
\end{tabular}

Referring table 10 to the results of this study showed that the average distribution of the mean score on the aspect of the technic is medium. The overall mean value indicates the average level of 3.61. There are six items on the high score and four items were if mean that simple.

Table 11. Distribution of mean scores for the aspects of workability.

\begin{tabular}{lll}
\hline statement Item & Min & Interpretation \\
\hline $\begin{array}{l}\text { I can communicate with people of different } \\
\text { races. }\end{array}$ & 4.35 & High \\
$\begin{array}{l}\text { I can communicate well in English language. } \\
\text { I can communicate well in Malay language. }\end{array}$ & 4.65 & Medium \\
$\begin{array}{l}\text { I can communicate ideas clearly and confidently } \\
\begin{array}{l}\text { in writing. } \\
\text { I can communicate ideas clearly and confidently }\end{array}\end{array}$ & 4.00 & High \\
$\begin{array}{l}\text { orally. } \\
\begin{array}{l}\text { I can carry out the instructions of the lecturer } \\
\text { well. }\end{array}\end{array}$ & 4.00 & High \\
\hline
\end{tabular}

\begin{tabular}{lll}
\hline statement Item & Min & Interpretation \\
\hline I will make discussions to reach an agreement. & 4.00 & High \\
$\begin{array}{l}\text { I can develop communication skills themselves. } \\
\text { I can provide feedback when communicating }\end{array}$ & 3.81 & High \\
$\begin{array}{l}\text { with others. } \\
\text { I can safely say "no" in the discussion prudently. }\end{array}$ & 3.81 & High \\
$\begin{array}{l}\text { I can identify problems in the practical operation } \\
\text { or workshop. }\end{array}$ & 3.36 & Medium \\
$\begin{array}{l}\text { I can make a clear judgment on an issue that } \\
\text { arises. }\end{array}$ & 3.32 & Medium \\
$\begin{array}{l}\text { I can make an analysis of the problem. } \\
\text { I can think outside of the context of the real. }\end{array}$ & 3.75 & High \\
$\begin{array}{l}\text { I will look for alternative ways of issues that } \\
\text { arise. }\end{array}$ & 4.39 & High \\
$\begin{array}{l}\text { I will refer to more people know when faced } \\
\text { with problems. }\end{array}$ & 4.10 & High \\
$\begin{array}{l}\text { I will take into account environmental factors in } \\
\text { problem solving. }\end{array}$ & 3.74 & High \\
$\begin{array}{l}\text { I have the skills to control stress better. } \\
\begin{array}{l}\text { I tried to assess the impact of every action and } \\
\text { decision. }\end{array}\end{array}$ & 3.35 & Medium \\
$\begin{array}{l}\text { I will not stop as long as it can not find a } \\
\text { solution to the problems faced. }\end{array}$ & 3.75 & Medium \\
$\begin{array}{l}\text { I use my own creativity in solving problems. } \\
\text { I think in detail the implications that occurs as a } \\
\text { result of the decision made. }\end{array}$ & 3.35 & Medium \\
$\begin{array}{l}\text { I easily adapt to various situations. } \\
\text { I am comfortable working with people of } \\
\text { different cultures. }\end{array}$ & 3.11 & Medium \\
$\begin{array}{l}\text { I can distinguish argument fundamentally } \\
\text { correct or otherwise well. }\end{array}$ & 3.39 & Medium \\
$\begin{array}{l}\text { I will make a decision based on sufficient } \\
\text { information. }\end{array}$ & 3.35 & Medium \\
$\begin{array}{l}\text { I plan in advance what to do if you want to } \\
\text { make something work. }\end{array}$ & 3.88 & High \\
$\begin{array}{l}\text { I always incorporate ideas from members of the } \\
\text { group to do a job. }\end{array}$ & 4.39 & High \\
$\begin{array}{l}\text { I can evaluate the spirit during the discussion. } \\
\text { I made a review of all decisions made in the } \\
\text { discussion. }\end{array}$ & 3.39 & Medium \\
Total Score Mean & 3.39 & Medium \\
\hline & 3.71 & High \\
\hline
\end{tabular}

Analysis conducted to answer the research question, namely whether there is a fourth gender differences in terms of technical skills that affect the willingness of students to the formation of workability. In this section, the researcher has tested this hypothesis. Statistical tests were used to test the hypothesis that the Mann Whitney U test.

\section{Findings and Discussion}

The findings of the results of statistical data analysis by descriptive and inferential as well as discussions and preparations findings, it was concluded that the overall answer the research questions outlined previously. The research question was based on a study in which the statement said had produced graduates who do not have technical skills covers the methods, procedures and techniques as required by the employer. So referring to the results of this study showed that the average distribution of the mean score on the aspect of the method is high. This means that students understand the technical aspects of the 
method for properly. According Towns et al. (2000), through the methods in technical skills, knowledge of students regarding the contents of the scientific skills

and problem solving skills will be obtained. Hence, the acquisition of skills that would indicate the likelihood of the formation of the characteristics of the human capital needed.

The degree of readiness of students of the procedural aspects of the establishment of workability, the findings, respondents who understand the rules of the workshop and safety symbols on the workshop got the highest mean score. It can be concluded that the procedure is very important when you're in the workshop. It is strengthened by Longley (1969), which states students or workers who lack the knowledge or unskilled to its terms of reference are more likely to make mistakes and prone to accidents. Through the results of this study showed that the average distribution of mean scores on the technical aspects of the medium. It shows the use of the right hand tool will produce quality work. According to Wan Azmi (1985), the quality of work lies not only in knowledge but the readiness skills in the operation of a machine tool and also a determining factor. This proves that the students have to know and understand and have the willingness to learn.

The readiness of students in terms of workability to be discussed include communication skills, problem solving and critical thinking. Through the results of the study skills of communication, mean scores showed a high level of respondent item can communicate with people of different races and can communicate ideas clearly and confidently orally. Rahman (2000) states that $80 \%$ of people who fail in his career is caused by their failure to communicate and connect with others. Part of the problem shows the item respondents could find an alternative route to the issues that arise have the highest mean score and the last part is critical thinking. Items that have the highest mean scores showed that respondents tend to incorporate ideas from members of the group to do a good job. According to Som and M. Dahlan (1998), critical thinking skills is the competence and capability of using the mind to assess the reasonableness or fairness of an idea, researching it short, kindness, weakness of an argument and make sound judgment by using reason and reasonable evidence. In contrast, the opinion Azizi, Noordin and Zurihanmi, (2005), critical thinking is an active learning about the observations and the information used as a guide for assessing and acting, thinking reflection that provides new understanding, interpretation of the knowledge-based observation and evaluation, an effort to understand evidence-based knowledge and reasoning, as well as an assessment of how demanding thinker controlling thought.

Next, the last part of the discussion focused on gender differences on aspects of technical skills covers the methods, procedures and techniques as well as the aspect of workability. The findings showed that there are differences between the sexes of the technical aspects that affect workability must have before they step into the working world in the future. The conclusion that can be said is a male student in three vocational colleges are more inclined towards technical skills and better workability. The researchers found the practical activities carried out by students in groups of men and women are monopolized by male students. According to Abd Ghani (2010), women are more interested in a clean job that does not involve vigorous activities and hands-on. This suggests that women are less interested in outdoor activities that require a lot of practical skills and hands-on and the next opportunity to make this activity more to men.

\section{Conclusion}

Overall, the researchers found that the studies that have been conducted can produce findings that answers to all research questions that have been raised. The findings were obtained by the two methods that mean and Mann Whitney U. To study the first, second, third, and fourth formulations that can be highlighted is the readiness of students of technical aspects of the students are on a high level. This includes technical aspects of the methods, procedures and techniques. The fourth research questions that students have a high willingness of the workability and the fifth research question that there are differences between the sexes in terms of technical skills that affect the willingness of students to the formation of workability.

According to the Education Development Plan 20132025 , vocational education prepares students to careers that require specialized technical expertise. The accounting career technical and vocational skills, ranging from carpentry to positions in engineering and other work. In contrast to the technical courses that prepare students to continue their education to a higher level, more careeroriented vocational stream. Industry demand for graduates of vocational students is high and will continue to rise. In 2008, the Ministry of Human Resources reported a shortage of skilled workforce of over 700,000 people in the manufacturing industry, agriculture and construction. The demand for skilled resources in the future will continue to increase. By 2020, of the 3.3 million jobs created under the NKEA, at least $46 \%$ require vocational qualification certificate or diploma, compared with $22 \%$ requiring university degree (Exhibit 7-6). To bridge the gap this request, there is a need to provide 50,000 additional places in vocational education each year.

In addition to these challenges, there are also other challenges, namely to ensure the quality of vocational education. Lack of qualified instructors, a curriculum that is not recognized by the industry, weak collaboration with the industry and training in a limited service, is the cause of graduates failed to meet the needs of industry. As a conclusion, all parties should play a role in shaping the human capital that will be an important asset for the country. This study actually gave the starting point to the parties concerned to find appropriate solutions to the problems related in order to produce a generation of skilled that can contribute to national development. 


\section{References}

[1] Abd Ghani, R. (2010). Iktiraf Penglibatan Wanita. Utusan Malaysia. Dicapai pada Januari 29, 2010, dari http://www.utusan.com.my

[2] Azizi Yahaya; Asmah Suboh; Zurihanmi Zakaria; Fawziah Yahya (2005). Aplikasi Kognitif dalam Pendidikan. Kuala Lumpur: PTS Professional Publishing. Kuala Lumpur.

[3] Dickson, M (2000), “Giving Undergraduates Managerial Experience”, Education + Training, Vol 42 No 3, pp 159-169.

[4] Elinor Edvardsson Stiwne\& Tomas Jungert. (2007). Engineering Students Experiences ofthe Transition from Study to Work. Proceedings of $3^{\text {rd }}$.

[5] Hesketh, A. C. (1999), "Towards a new economic sociology of the student financial experience of higher education." Journal of Education Policy.

[6] Idris, P. D. U. P. S., \& Patta, S. D. B. (2013), Pengaruh Demografi Terhadap Penguasaan Kemahiran Insaniah Dalam Kalangan Pelajar Program.
[7] Pendidikan: Tesis Sarjana. Universiti Tun Hussein Onn Malaysia.

[8] International CDIO Conference. MIT, Cambridge, Massachusetts.

[9] Konting, M, 2009, Kaedah Penyelidikan Pendidikan cet.ke8, DBP: Kuala Lumpur.

[10] Longley (1969). "Safety Education And Training, Safety On Construction Site". London: The Institution Of Civil Engineering.

[11] Mahathir, M. (2003). Teks Ucapan "Bersedia Hadapi Cabaran Uji Kecekapan Dan Kemampuan Kita”. Berita Harian 31 Oktober 2003, m/s 14.

[12] Rahman, R. A. (2010), Kesan Latihan Kemahiran Berkomunikasi Terhadap Konsep Kendiri Pelajar Di Sebuah sekolah Menengah. Jurnal Pendidikan Malaysia.

[13] Som Hj Nor dan Mohamad Dahalan Mohd Ramli (1998). Kemahiran Berfikir Secara Kritis dan Kreatif (KBKK). Selangor. Pearson Malaysia Sdn Bhd. 